\title{
Study of Atlas Cedar Growth (Cedrus atlantica Manetti) in El M'sid Mountains (East Algeria): Productivity and Growth According to Planting Methods
}

\author{
Amina Keriem¹, Mohamed Sbabdji ${ }^{*}$, Luc Lambs ${ }^{2}$ \\ ${ }^{1}$ Forestry Departement, Ecole National supéRieure Agronomique, El Harrach, Algeria \\ ${ }^{2}$ CNRS-ECOLAB, Toulouse, France \\ Email: aminakeriem@gmail.com, *sbabdji_mohamed@yahoo.fr, ‘m.sbabdji@ensa.dz, \\ luc.lambs@univ-tlse3.fr
}

How to cite this paper: Keriem, A., Sbabdji, M., \& Lambs, L. (2018). Study of Atlas Cedar Growth (Cedrus atlantica Manetti) in El M'sid Mountains (East Algeria): Productivity and Growth According to Planting Methods. Open Journal of Forestry, 8, 182-195. https://doi.org/10.4236/ojf.2018.82013

Received: January 28, 2018

Accepted: April 17, 2018

Published: April 20, 2018

Copyright $\odot 2018$ by authors and Scientific Research Publishing Inc. This work is licensed under the Creative Commons Attribution International License (CC BY 4.0).

http://creativecommons.org/licenses/by/4.0/

\begin{abstract}
The Atlas cedar (Cedrus atlantica) is one of the more valuable reforestation species in the Mediterranean areas. But this species suffers from rainfall limitation and climate changes, particularly in its originated area, North Africa. Therefore, any knowledge about the plantation practices to improve the tree water availability and the reforestation success has great importance. The current study has been undertaken in this view, i.e. to compare the growth of cedar plots located in El M'Sid Mountains, Souk Ahras department $(700 \mathrm{~km}$ east of Algiers), according to different planting methods. The radial growth and the productivity have been measured on a cedar plot with a total surface of 165 ha. 150 ha has been planted in 1970 on hillside ditches, and 15 ha of which the majority is planted in a simple hole and some bouquets on terraces, both are originated from a complementary reforestation achieved during 1980. The results show that most of the trees planted in 1970 reach a height ranging between 10 and $17 \mathrm{~m}$ and a diameter between 23 and $44 \mathrm{~cm}$. Even some trees were $20 \mathrm{~m}$ high with diameter of $65 \mathrm{~cm}$. The productivity fluctuates between 3 and $8 \mathrm{~m}^{3} / \mathrm{ha} /$ year, values close to the one of natural native plots. Trees planted in 1980 reach a height ranging between 5.5 to $7 \mathrm{~m}$, and diameter between 11.5 to $23 \mathrm{~cm}$. The radial growth improves that the hillside ditches help the roots anchoring and trees growth during the first season after plantation. These results indicate that the cedar tree can be used with success in areas outside the natural cedar forest presence, and that appropriate planting techniques can compensate in part the lower rainfall occurring in these chosen regeneration areas.
\end{abstract}




\section{Keywords}

Atlas Cedar, El M’Sid Mountains, Tree Productivity, Radial Growth, Hillside Ditches

\section{Introduction}

With its ecological plasticity (Savill \& Wilson 2015), its good wood production both quality and quantity (El Azzouzi \& Keller 1998; Messaoudène et al., 2004), the Atlas cedar is considered as a noble species in its originated area, the North African. Effectively, this species can grow under a wide range of biotope corresponding to all areas between 1200 and $2400 \mathrm{~m}$ of altitude and sub-humid to per-humid climate (Harfouche \& Nedjahi 2003; M’Hirit \& Benzyane 2006, Demarteau et al., 2007) where it can provide yearly between 4 and $5 \mathrm{~m}^{3} / \mathrm{ha}$ of good wood (Bentouati \& Oudjehih 1999).

Additionally to their forest considerations, the cedar forests are well appreciated for its aesthetic qualities (Courbet \& Alboudy 1993; Toth 1990), and their resistance to drought, to limestone soil and to fire. For those numerous advantages; cedar is designed by many authors (M'Hirit 1999; Harfouche \& Nedjahi 2003) as a main species for the mountains reforestation, above 1000 to $1200 \mathrm{~m}$ altitude, and for the valorization of unproductive or damaged forest under Mediterranean climate. In the same context, Messaoudène et al. (2004) indicate that the cedar forest in Algeria occupies 20,000 ha, but its climatic area is larger.

Moreover, and because of the success of its introduction in different European countries since $19^{\text {th }}$ century (Cointat 1996; Nedjahi, 1987), it has been mentioned among the priority research subject by Mediterranean Forestry Committee during its $12^{\text {th }}$ session held in Rome 1986. Its surface in France has exceeded 10,000 ha before the end of past century (Toth 1980).

In Algeria, one of his two origin countries with Morocco, this species has not found yet such favourable consideration. Aside from the privilege granted to their natural stands in protected areas, there are few development programs for the cedar plantations. Indeed, the cedar forests is composed mainly by natural forest, the reforestations areas are very few, in spite of a great number of researches focusing on the advantage of cedar forest extension. Several among these works, suggest that the cedar trees can significantly improve the ecological and economical role of forest (El Azzouzi \& Keller, 1998; Lefievre et al., 2010; Savill \& Wilson, 2015) in spite of the difficulties related to climate change (Linares et al., 2011). Indeed, recent work shows that the native northern stands of cedar behave normally and allow the best protection of the high parts of the watersheds, despite the high tourist pressure and the defoliations by the pine processionary moth (Thaumetopoea pytiocampa Schiff) (Sbabdji 2012). Other works indicate that the cedar area in Blidian Atlas (centre part of North Algeria) may be extending by reforestation from 1200 to 5000 ha (Dehilis \& Bouakline, 2013). 
If in northern stations, the cedar trees can be established on large area without inconvenient, in comparison with the southern stations, where the natives plantations are much affected by rainfall deficit and higher temperature (Bentouati \& Bariteau 2006; Courbet et al. 2012; Linares et al. 2013). New investigations must be carried out to clarify this question and to define the areas and techniques of cedar reforestation.

Dispersed all over the Tellian Atlas (Northern part of Algeria) in small woody plots, cedar reforestations have been tested in different watershed. In this purpose, the present work reports the case of the cedar plantation of El M'sid Mountains in Souk Ahras department. Located in the North-eastern part of Algeria, these trees have been planted during 1970s and completed in 1980s. The first aim of this study is to estimate the potentiality wood productivity of cedar tree in this area, from the 70s plantation. The second aim is to compare different planting methods: hillside ditches (in 70s plantation), on terrace and in simple hole (in 80s plantation) on the cedar growth speed, by comparison of the tree height, the circumference and the radial growth.

\section{Materiel and Methods}

\subsection{Study Area}

The study area is named Djebel El M'sid, which is part of Mount Medjerda $\left(36.4075^{\circ} \mathrm{N}-36.3875^{\circ} \mathrm{N}, 8.0525^{\circ} \mathrm{E}-8.0725^{\circ} \mathrm{E}\right)$ is located $20 \mathrm{~km}$ south-east of Souk Ahras city and 700km eastern of Algiers (Figure 1).

Peaking at $1400 \mathrm{~m}$, it is characterized by an average slope (10\% to $30 \%)$ and a fresh humid bioclimate with an annual precipitation ranging between 800 and $900 \mathrm{~mm}$. The substrate is dominated by Numidian sandstones leading to the sandy clay (siliceous). The natural vegetation is dominated by grasses lawns containing some shrubs, the most common are Calicotome spinosa, Ampelodesma mauritanica, Asphodelus microcarpus, Crataegus monogyna and Erica arborea.

\subsection{Cedar Plantation}

It should be recalled that the work concerns two parts of different ages (Figure 1(a)). The first part covers 150 ha planted on hillside ditches during the 70 s (1970-1975), the other younger, is from a complementary reforestation performed on 15 hectares during the $80 \mathrm{~s}$, for its most part the trees was planted in the simple holes, the remaining is small bouquet planted on terraces. Thus the reforestation area is divided on two parts, according to the trees age, but on three parts according to the planting methods. That of 1970 is disposed in line following the hillside ditches, which are oriented according to the level curves. The hillside ditches are 2.5 to $3 \mathrm{~m}$ width, including the downhill ridge, the uphill ditch and the middle nearly flat part flat. The trees were planted on the inferior border of the hillside ditches (see Figure 1(b)). The spacing is of $3 \mathrm{~m}$ between trees and $30 \mathrm{~m}$ between the hillside ditches. For the plots of 1980s, the trees were 


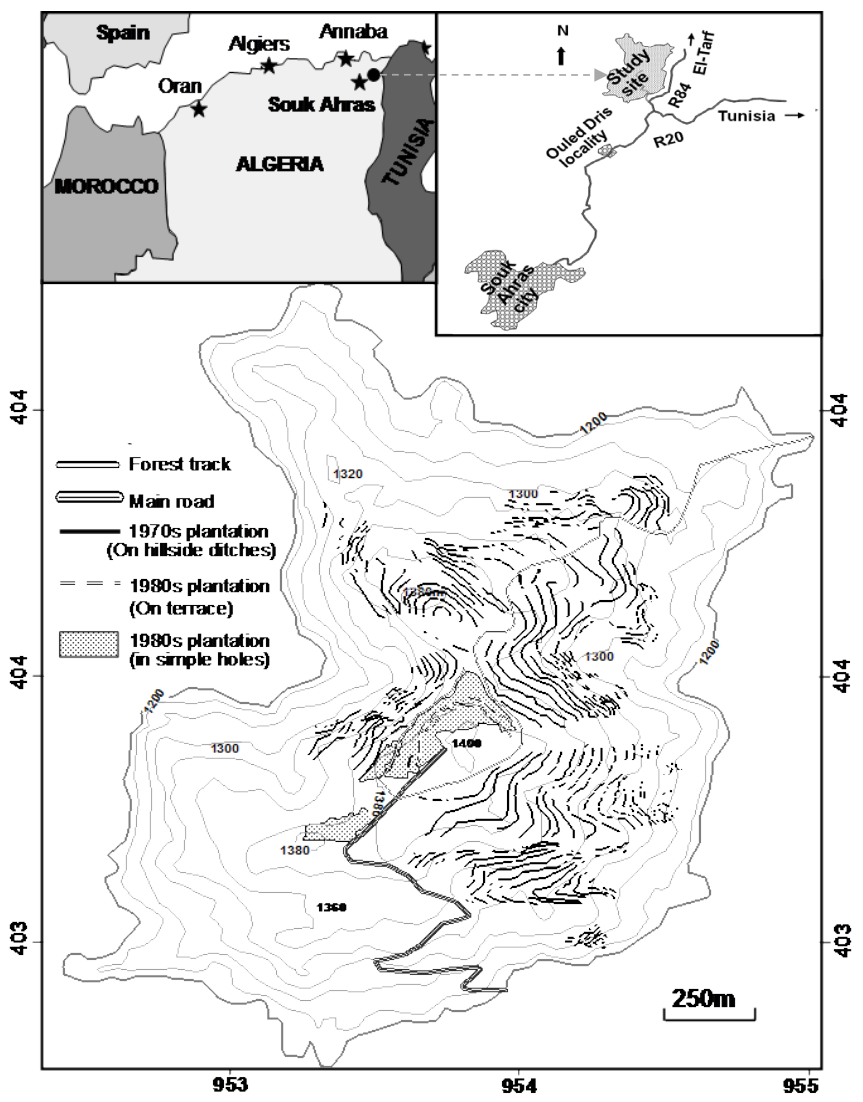

(a)

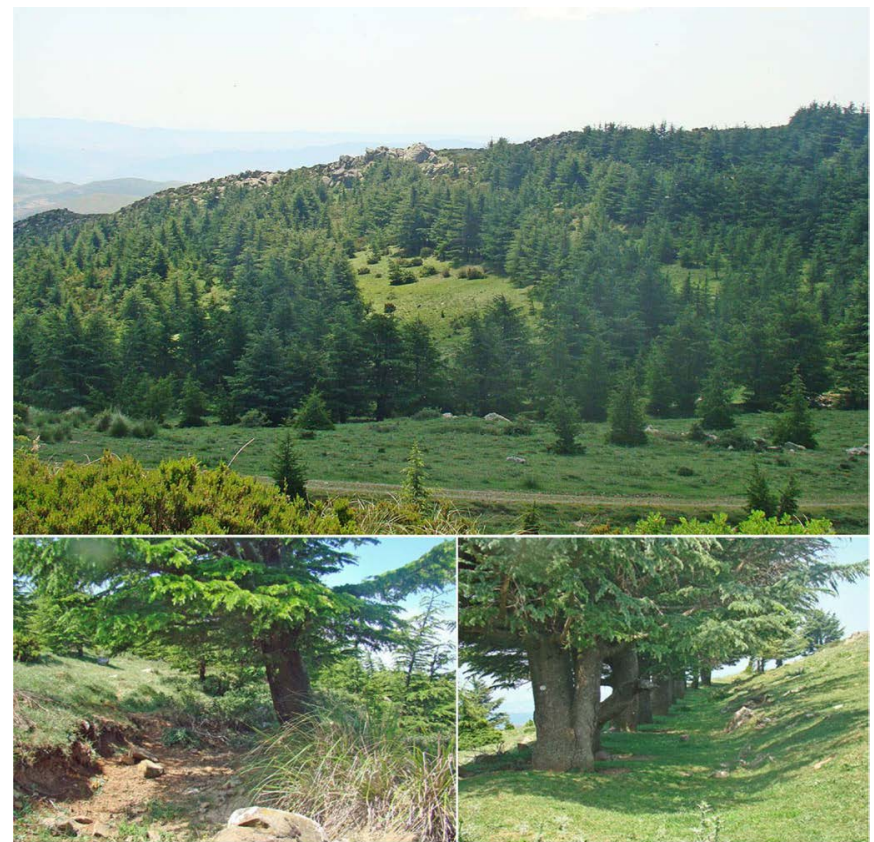

(b)

Figure 1. (a) Localisation and structure of cedar planting plots in El M'sid Mountain (map drawn with Map Info v 7.0, from original Google Map satellites views from 2013). (b) General view of the studied site (up) and the different planting methods: terrace (left) and hillside ditches (right). 
planted in simple hole and spaced from 3 to $4 \mathrm{~m}$; those on terrace are slightly tight, between 2 and $3 \mathrm{~m}$ of spacing.

\subsection{Sampled Plot}

Because the trees are line up (for those on terrace and on hillside ditches), it was not possible to work with traditional on the circular or square $400 \mathrm{~m}^{2}$ plots (Rondeux 1999). Therefore, it was essential to select elongated rectangular plots corresponding to plantation lines. Due to the size and tree density heterogeneity the study plots were randomly chosen in each of the four cardinal directions (East, South, West, North). Thus for the trees planted in the 1970s, dendrometric measurements have been realised in these four directions in triplicate (Table 1).

According the norms of dendrometric sampling (Parde \& Bouchon 1988), each measured plot contains at least 25 trees, which corresponds to a length of $75 \mathrm{~m}$. The plot width were fixed to $5 \mathrm{~m}$ according to the vital space of trees, this gives a surface plot area of $75 \times 5=375 \mathrm{~m}^{2}$. The same sampling system were applied for the terrace trees areas, but in only one plot (due to the smaller area). For the planted trees areas planted in a simple hole, the sampling plots have a circular form of $400 \mathrm{~m}^{2}$.

\subsection{Dendrometric Measurements}

The girth at breast height and the total height were measured for all trees in all plots. The Pressler height (height corresponds of half diameter) is taken on five trees by plot, for those planted in 1970s. Girths were taken with a measuring tape, the height by a Bitterlich relascope.

\subsection{Wood Productivity Calculation}

The wood productivity calculation which concerns only the 70 s plantation requires three steps:

In the first one concerns the estimation of the tree volume $(\mathrm{Vp})$ with the Pressler formula. This calculation requires the determination of the diameter at breath high for the calculation of the corresponding surface (So) and the

Table 1. Sampled plots description.

\begin{tabular}{|c|c|c|c|c|c|c|}
\hline Sites & 1 & 2 & 3 & 4 & 5 & 6 \\
\hline Planting methods & \multicolumn{4}{|c|}{ Hillside ditches } & Simple hole & Terrace \\
\hline Planting date & \multicolumn{4}{|c|}{1970} & \multicolumn{2}{|c|}{1980} \\
\hline Altitude (m) & 1363 & 1345 & 1351 & 1312 & 1389 & 1380 \\
\hline Slope (\%) & 20 & 20 & 30 & 15 & 10 & 15 \\
\hline Cardinal direction & East & South & West & North & West & West \\
\hline Coordinates & $8.058^{\circ}$ & $8.057^{\circ}$ & $8.053^{\circ}$ & $8.064^{\circ}$ & $8.055^{\circ}$ & $8.056^{\circ}$ \\
\hline (Long. et Lat.) & $36.400^{\circ}$ & $36.394^{\circ}$ & $36.398^{\circ}$ & $36.406^{\circ}$ & $36.399^{\circ}$ & $36.399^{\circ}$ \\
\hline Plot number & 3 & 3 & 3 & 3 & 2 & 1 \\
\hline
\end{tabular}


measurement of the Pressler's height $\left(h_{p}\right)$ with the Relascope (Duplat \& Perrotte 1981; Parde \& Bouchon 1988) according to the formula (Rondeux 1993):

$$
V p=2 / 3 \text { So }\left(h_{p}+b / 2\right)
$$

with $b=1.30 \mathrm{~m}$. This calculation was only used on the trees chosen to be measured for Pressler height (five per plot).

The second step consists of aregression calculation to find the best fit between $V p$ and the volume calculated only from the girth (i) and tree height $(h)$. This relationship $V=f(c, h)$, was then applied to calculated the tree volume for the other trees were the Pressler height $\left(h_{p}\right)$ was not determined.

In the third step, the wood production and productivity were determined. The wood volume by plot is given by addition of trees single volumes. Thereafter, the volume by hectare is extrapolated according to the surface plot. The real productivity $\left(\mathrm{m}^{3} / \mathrm{ha}\right.$ /year) is calculated by dividing the production with the tree age. The potential productivity is calculated if the free space $(30 \mathrm{~m})$ let between the trees lines for the hillside ditches, were planted with additional tree lines every 5 meters.

\subsection{Radial Growth Measurements}

For the radial growth measurement, twelve trees were sampled in each planting type plot. A total of 36 increment cores were taking from the dominant trees. The wood cores were glued onto wooden mounts. After drying, fine sandpaper was used to improve the tree rings discrimination. After preliminary dating, ring widths were measured with the help of a calibrated microscope under $\times 10$ magnification. This measurement was used to compare the planting techniques on trees growth and to see how its change over the years.

\subsection{Statistical Analysis}

The data were analysed using the EXCEL and the XLSTAT Pro 7.1 (Microsoft Corporation, Washington, USA), Analyses of variance (ANOVA) and non-parametric Kruskal-wallis.

\section{Results}

\subsection{Dendrometric Analysis and Woody Productivity Potential}

\subsubsection{Height Growth}

The results show that the tree height ranges between 3 and $20 \mathrm{~m}$ (Table 2). However, the height values in the three first sites $(6.5$ to $20 \mathrm{~m})$ were relatively homogeneous (CV $\leq 17 \%$ for the majority of cases) and higher than those of $4^{\text {th }}$ site which were smaller ( 3 to $17 \mathrm{~m}$ ) and more variable $(28 \% \leq \mathrm{CV} \leq 34 \%)$. The smaller heights in this $4^{\text {th }}$ site were also seen by the low mean values observed in its three sample plots $(9.89,10.15$ and $10.18 \mathrm{~m})$, whereas for the other sites the mean value was generally over $12 \mathrm{~m}$ in height. The trees height was significantly variable between sites $(\mathrm{f}=37.25$, d. $\mathrm{f}=3, \mathrm{P}<0.0001$, for $\mathrm{p}=0.05)$ and between 
Table 2. Summary table of trees sizes variation, heights and girths in the sampled plots.

\begin{tabular}{|c|c|c|c|c|c|c|c|c|c|c|c|}
\hline \multirow{2}{*}{ Sites } & \multirow{2}{*}{ Plots } & \multicolumn{3}{|c|}{ Height (m) } & \multicolumn{2}{|c|}{ Variation } & \multicolumn{3}{|c|}{$\begin{array}{l}\text { Girth } \\
(\mathrm{cm})\end{array}$} & \multicolumn{2}{|c|}{ Variation } \\
\hline & & $\mathrm{H}_{\min }$ & $\mathrm{H}_{\max }$ & $\mathrm{H}_{\text {mean }}$ & $\begin{array}{c}\text { Between } \\
\text { trees }\end{array}$ & $\begin{array}{c}\text { Between } \\
\text { plots }\end{array}$ & $\mathrm{C}_{\min }$ & $\mathrm{C}_{\max }$ & $\mathrm{C}_{\text {mean }}$ & $\begin{array}{c}\text { Between } \\
\text { trees }\end{array}$ & $\begin{array}{c}\text { Between } \\
\text { plots }\end{array}$ \\
\hline \multirow{3}{*}{1} & 1 & 7.0 & 11.8 & 10.25 & $8.61 \%$ & & 60 & 160 & 107.28 & $24 \%$ & \multirow{3}{*}{ NS } \\
\hline & 2 & 8.0 & 14.5 & 12.68 & $13 \%$ & $* *$ & 40 & 140 & 95.56 & $27 \%$ & \\
\hline & 3 & 10.5 & 17.0 & 13.51 & $28 \%$ & & 30 & 170 & 105.41 & $34 \%$ & \\
\hline \multirow{3}{*}{2} & 1 & 14.0 & 20.0 & 17.49 & $17 \%$ & & 44 & 180 & 127.12 & $28 \%$ & \multirow{3}{*}{ NS } \\
\hline & 2 & 6.5 & 15.0 & 12.19 & $17 \%$ & $* *$ & 38 & 204 & 121.7 & $27 \%$ & \\
\hline & 3 & 9.5 & 16.9 & 14.35 & $17 \%$ & & 50 & 187 & 116.16 & $35 \%$ & \\
\hline \multirow{3}{*}{3} & 1 & 11.8 & 16.0 & 13.87 & $9.4 \%$ & & 80 & 190 & 126.48 & $26 \%$ & \multirow{3}{*}{ NS } \\
\hline & 2 & 11.5 & 16.2 & 14.91 & $8.1 \%$ & $* *$ & 70 & 200 & 138.2 & $24 \%$ & \\
\hline & 3 & 12.0 & 17.0 & 14.43 & $10 \%$ & & 100 & 210 & 146.6 & $22 \%$ & \\
\hline \multirow{3}{*}{4} & 1 & 3.1 & 14.0 & 9.89 & $34 \%$ & & 25 & 113 & 70.5 & $37 \%$ & \multirow{3}{*}{ NS } \\
\hline & 2 & 4.2 & 13.8 & 10.15 & $28 \%$ & NS & 25 & 118 & 74.68 & $34 \%$ & \\
\hline & 3 & 3.4 & 15.0 & 11.16 & $31 \%$ & & 20.5 & 135 & 74.76 & $41 \%$ & \\
\hline
\end{tabular}

(Kruskall-Wallis Test for variation between plots and variation coefficient for between trees).

plots for the first three plots. Globally the best height growth was observed in the second plot, whereas the lower was recorded in the fourth one.

\subsubsection{Diameter Growth}

The analysis of girth growth have revealed similar results with those of height for the variation between sites $(\mathrm{F}=42.75$, d.f. $=3, \mathrm{P}<0.0001)$, but the variation was more high between trees $(\mathrm{CV} \geq 22 \%)$ and not significant between plots of same site. As for the heights, the lower mean values was recorded in the fourth plot $(70.5,74.68$ and $74.76 \mathrm{~cm}$ ), those of second and third plots were the higher (from 116.16 to $146.6 \mathrm{~cm})$.

\subsubsection{Volume Growth}

After testing numerous equations for the volume estimation by height and diameter $(V=f(d, h)$, we used the one reported by Rondeux (1993), who corresponds to high value of coefficient of determination: $\mathrm{V}=0.109-1.121 \mathrm{~d}+$ $3.761 d^{2}+3.16 E-02 d^{2} h$. Except the fourth plot where the tree growth were presumably affected by grazing, the wood volume of this plantation fluctuate between 149 (first site) and $301 \mathrm{~m}^{3} / \mathrm{ha}$ (third site) (Table 3). These values correspond to $100 \%$ of difference between plots. On the other hand, the variation between plots of same sites remains relatively weak (CV values are respectively $13.24,20.24,21.77$ and 18.01 for the plots 1, 2, 3 and 4 respectively). With regard of wood volume values, growth fluctuates between 0.53 and $1.36 \mathrm{~m}^{3} / \mathrm{ha} /$ year according the plots and it varies from $0.59 \pm 0.08$ to $1.2 \pm 0.26 \mathrm{~m}^{3} / \mathrm{ha} /$ year in function of the sites. 
Table 3. Summary of the real $\left(\mathrm{V}_{\mathrm{R}}\right)$ and potential $\left(\mathrm{V}_{\mathrm{P}}\right)$ growth of woody volume.

\begin{tabular}{cccccccc}
\hline Plots & Plots & $\begin{array}{c}\text { Volume } \\
\left(\mathrm{m}^{3}\right)\end{array}$ & $\begin{array}{c}\mathrm{V}_{\mathrm{R}} \\
\mathrm{m}^{3} / \mathrm{ha}\end{array}$ & $\begin{array}{c}\mathrm{V}_{\mathrm{P}} \\
\left(\mathrm{m}^{3} / \mathrm{ha}\right)\end{array}$ & $\begin{array}{c}\mathrm{V}_{\text {Pmean }} \\
\left(\mathrm{m}^{3} / \mathrm{ha}\right)\end{array}$ & $\begin{array}{c}\text { Real productivity } \\
\left(\mathrm{m}^{3} / \text { ha/year }\right)\end{array}$ & $\begin{array}{c}\text { Potential productivity } \\
\mathrm{m}^{3} / \text { ha/an }\end{array}$ \\
\hline \multirow{3}{*}{1} & 1 & 5.36 & 23.82 & 142.93 & & 0.57 & 3.40 \\
& 2 & 5.03 & 22.36 & 134.13 & 149 & 0.53 & 3.19 \\
& 3 & 6.45 & 28.67 & 172.00 & & 0,68 & 4.10 \\
& 1 & 8.63 & 38.36 & 230.13 & & 0.91 & 5.48 \\
2 & 2 & 7.13 & 31.69 & 190.13 & 191 & 0.75 & 4.53 \\
& 3 & 5.73 & 25.47 & 152.80 & & 0.61 & 3.64 \\
& 1 & 8.48 & 37.69 & 226.13 & & 0.90 & 5.38 \\
& 2 & 12.62 & 56.09 & 336.53 & 301 & 1.34 & 8.01 \\
& 3 & 12.87 & 57.20 & 343.20 & & 1.36 & 8.17 \\
& 1 & 1.42 & 6.31 & 37.87 & & 0.15 & 0.90 \\
4 & 2 & 1.63 & 7.24 & 43.47 & 45 & 0.17 & 1.03 \\
& 3 & 2.02 & 8.98 & 53.87 & & 0.21 & 1.28 \\
\hline
\end{tabular}

According to these values, the potential productivity varies from 3.19 to 8.17 $\mathrm{m}^{3} / \mathrm{ha}$ /year through the sampled plots and from $3.56 \pm 0.47$ to $7.19 \pm 1.57$ $\mathrm{m}^{3} / \mathrm{ha} /$ year in function of the sites. The mean growth is $4.09 \pm 2.42 \mathrm{~m}^{3} / \mathrm{ha} /$ year, but can reach $5 \mathrm{~m}^{3} /$ ha/year $(5.10 \pm 1.87)$ after exclusion of the fourth plot.

\subsection{Effect of Plantation Methods on Trees Growth}

\subsubsection{In Term of Height and Girth}

With regard to the plantation of 1980, the results show that the trees grew better on terrace than in simple holes (Figure 2). Their mean size is $7.3 \pm 153 \mathrm{~m}$ (from 4.3 to $10.4 \mathrm{~m}$ ) of height and $72 \pm 25.2 \mathrm{~cm}$ (from 21 to $120 \mathrm{~cm}$ ) of girth on terrace, but for the case of simple hole planting, the two plots have respectively, $5.42 \pm 1.08 \mathrm{~m}$ and $5.57 \pm 1.20$ (from 2.3 to $8.4 \mathrm{~m}$ ) for height, $36.3 \pm 9.55$ and $37.35 \pm 13.27$ (from 19 to $75 \mathrm{~cm}$ ) for girth.

The mean yearly growth on terrace is $22.8 \mathrm{~cm}$ for height and $2.25 \mathrm{~cm}$ for girth, for trees planted in simple hole it's only 16.87 and $17.4 \mathrm{~cm}$ for height, 1.13 and $1.17 \mathrm{~cm}$ for girth. Thus the difference is significant for the two parameters, height $(\mathrm{F}=42.75, \mathrm{df}=3, \mathrm{P}<0.0001)$ and girth $(\mathrm{F}=42.75, \mathrm{df}=3, \mathrm{P}<0.0001)$. For both, on terrace and in simple hole, the trees growth remains very limited compared to those planted on hillside ditches where the annual growth range from 24.4 to $41.64 \mathrm{~cm}$ of height and from 2.27 to $3.49 \mathrm{~cm}$ for the girth (the forth site is exclude from comparison). On hillside ditches, the mean yearly growth of height (sites 1, 2 ant 3 combined) is $32.72 \pm 4.7 \mathrm{~cm}$ are $90.88 \%$ more high than in simple holes and $43.4 \%$ than on terrace, for the case of girth, the corresponding gain is of $149.3 \%$ and $27.5 \%$.

\subsubsection{In Term of Radial Growth}

The radial growth of tree planted on hillside ditches was higher than those on terraces or in simple hole (Figure 2). This difference was visible only during the 


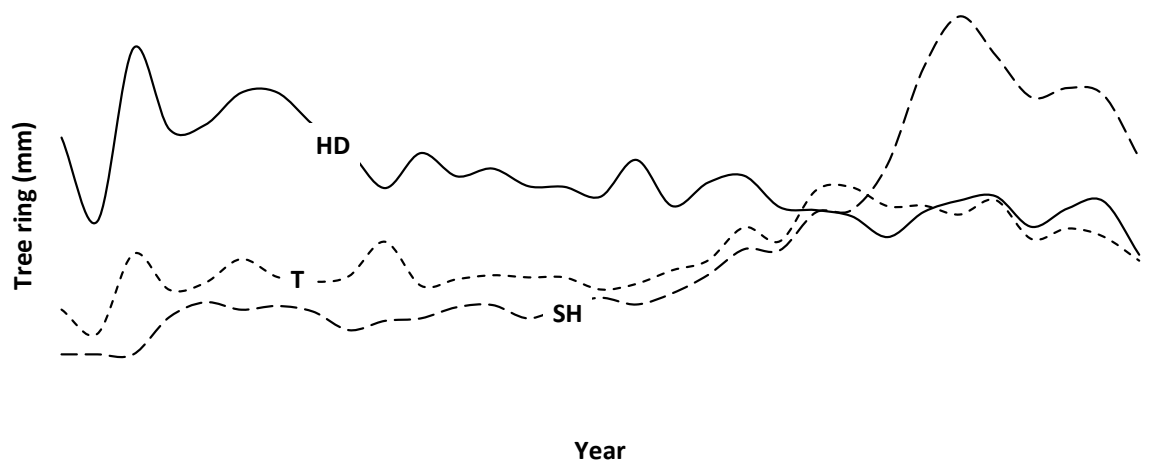

Figure 2. Mean radial growth following the planting methods on hillside ditches (HD), terrace $(\mathrm{T})$ and in simple holes $(\mathrm{SH})$.

young age, before 2002 when the 70s trees were 30 years old and those of $80 \mathrm{~s}$ about 20 years. For example, between 1985 and 2002, the values of mean ring was $5.12 \mathrm{~mm}$ for trees on hillside ditches but only 2.24 and $1.43 \mathrm{~mm}$ for tree on terraces ant those planted in simple holes. Subsequently the situation was reversed by the effect of density because the trees on hillside ditches and on terraces are very tight (spacing $\leq 3 \mathrm{~m}$ ) but those in simple holes are too spaced (spacing $\geq 5 \mathrm{~m}$ ). The higher growth rate was obtained by trees planted after 25 year, but decline after.

The superposition of growth profiles following age of trees shows that between 14 and 22 years of age, the trees on hillside ditches have recorded 1.45\% and $2.45 \%$ of growth gain than those on terraces and in simple hole (Figure 3 ).

It should be noted that this difference is independent of the climate (rainfall) because the mean annual quantities of precipitation during the two corresponding periods (1986-1991, 1996-2001) are advantageous for the trees planted in the $80 \mathrm{~s}$ on terrace and in simple holes (618.7 and $689.8 \mathrm{~mm}$ respectively).

\section{Discussion}

This work reports the cedar reforestation of El M'Sid mountain (Wilaya of Souk Ahras), achieved during the 70s and 80s. Firstly, it allowed to evaluate the wood potentiality of this species in this area and secondly to determine the effect of different planting methods (on hillside ditches, on terrace and in simple hole) on trees growth. The overall results show that this reforestation works fine. Indeed, for the majority of 1970s planted plots, the mean size of trees excess $10 \mathrm{~m}$ in height and $30 \mathrm{~cm}$ of diameter $(1 \mathrm{~m}$ girth). These values are similar or higher than those from many cedar native plots of the same age (Haddad 1998, Larbi Rezig 2011, Chellabi 1992) and see Table 4.

The wood productivity ranges between 3 and $8 \mathrm{~m}^{3} / \mathrm{ha} /$ year shows that these planted plots are as productive as the native cedar plots in Chrea area (Chellabi 1992). The values of the most fertile plots (plot 3) exceeding $8 \mathrm{~m}^{3} / \mathrm{ha} /$ year $(8.01$ and $8.17 \mathrm{~m}^{3} /$ ha/year), are close to planted plots in same area achieved during the same period (10.8 $\mathrm{m}^{3} / \mathrm{ha} /$ year) (Larbi-Rezig 2011). Note that these values 


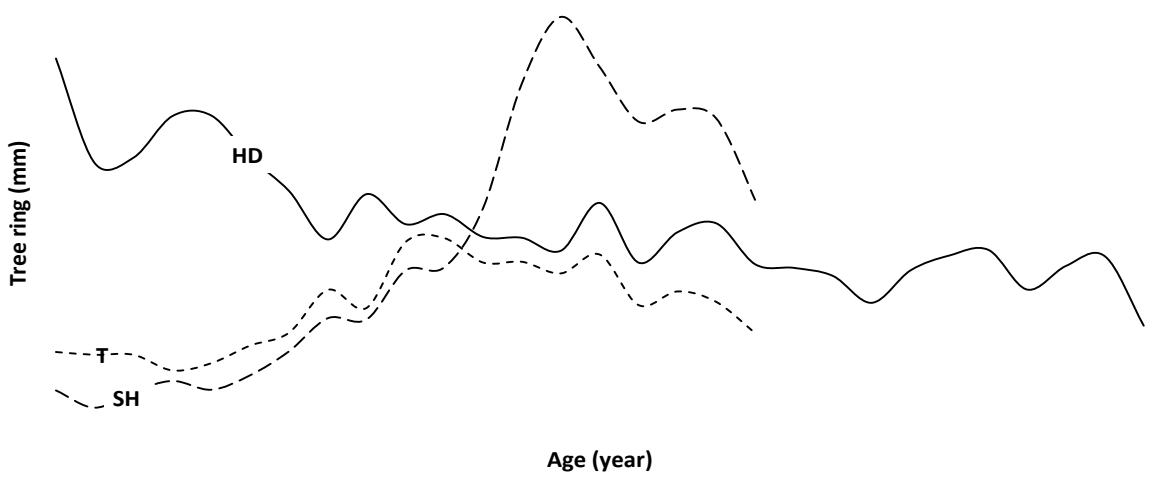

Figure 3. Evolution of radial growth according planting methods (HD: on hillside ditches, T: terraces, SH: simple holes).

coincide very closely with those announced by other authors for others Mediterranean areas (Toth, 1973; M’hirit 1999), see also Table 4.

The wood volume measures indicate globally that the yearly growth of cedar forest in this area is about 4 and $5 \mathrm{~m}^{3} / \mathrm{ha}$, what is mentioned for its potentiality through its origin area (Morocco and Algeria) (Nedjahi 1987; M’hirit 1994; Bentouati \& Oudjehih 1999).

In terms of radial growth, the results support those announced above and show that growth rate of this planted cedar plots is similar to those from others native cedar forest. Indeed, for the trees planted during the 1970s, the average radial growth fluctuates between 2.9 and $8.2 \mathrm{~mm} /$ year is closed to those of humid cedar forests in the Rif in Morocco (3 to $8 \mathrm{~mm}$ /year) and are considerably higher than those of southern cedar forest in Morocco $(0.8$ - 3.5) and Algeria (0.62 $-1.14 \mathrm{~mm} / \mathrm{an}$ ) (Messaoudène et al. 2004). Moreover, the mean of yearly radial growth $(4.8 \pm 1.05 \mathrm{~mm})$ is very close to that of reforestation achieved during the same period (5.36 \pm 1.5$)$ (Sbabdji et al. 2015) in Chrea area, where the cedar finds its best climatic conditions (more than $1000 \mathrm{~mm} / \mathrm{year}$ ) (Meddour 2002; Harfouche \& Nedjahi 2003). However, we must not forget that this growth implies besides the natural factors of plot, the soil improvement induced by the hillside ditches.

The comparison of radial growth following the methods of plantation shows that the trees planted on hillside ditches grew more quickly during their young age. They have recorded an average annual gain of $40.7 \%$ and $31.3 \%$ compared to those on terrace and those planted in simple hole, respectively. Noted that this gain would be more important in case of similar planting density; in other words, the low density of the trees planted in the simple holes have partially hidden the positive effect of the benches.

Although the use of hillside ditches in reforestation actions was toughly questioned because the high price of their implementation, this work demonstrate the efficiency of such planting method, and positive effect of tree growth during the first years. In addition to their role in a better roots anchorage, the ditch improves the water and minerals supply. Many authors have proposed the usefulness of hillside ditches and terraces, which protects the soil against erosion and 
Table 4. Some growth index of Atlas cedar in north Africa and France from the references : Bentouati \& Oudjehih (1999), Laaribya \& Belghazi (2016), M'hirit (1994), Toth (1970), Larbi-Rezig (2011), Dehilis \& Bouakline (2013), Zemirli (2006), and from this work on last line, with ${ }^{*}$ : hillside ditches, ${ }^{* *}$ : terrace and ${ }^{* *}=$ simple hole.

\begin{tabular}{|c|c|c|c|c|c|c|c|}
\hline & $\begin{array}{l}\text { Country } \\
\text { Area }\end{array}$ & climate stage & $\begin{array}{l}\text { Rainfall } \\
\mathrm{mm} / \text { year }\end{array}$ & Height (m) & Girth (cm) & $\begin{array}{l}\text { Productivity } \\
\mathrm{m}^{3} / \text { ha/year }\end{array}$ & $\begin{array}{c}\text { Radial growth } \\
\mathrm{mm} / \text { year }\end{array}$ \\
\hline \multirow{3}{*}{ Morocco } & Rif occidental & Humid & $1390-1786$ & $12-27$ & & $3.5-8.30$ & $3-8$ \\
\hline & Moyen-Atlas tabulaire & $\begin{array}{l}\text { Subhumid } \\
\text { to humid }\end{array}$ & $871-1066$ & $18-36$ & & $1.42-4.65$ & \\
\hline & Moyen-Atlas oriental & $\begin{array}{l}\text { Semi-arid } \\
\text { to subhumid }\end{array}$ & $615-927$ & $12-30$ & & $0.78-3.48$ & $0.8-3$ \\
\hline \multirow[t]{4}{*}{ France } & South of France & - & $800-1400$ & $13-32.5$ & $57-145$ & $7.2-12.8$ & $7.2-12.8$ \\
\hline & $\begin{array}{c}\text { Belezma } \\
\text { Natif plantation }\end{array}$ & Semi-arid & $499-790$ & $5.83-22.8$ & $79-363$ & $0.15-5.14$ & $0.61-3.43$ \\
\hline & $\begin{array}{l}\text { Teniet el Had } \\
\text { Natif plantation }\end{array}$ & Subhumid & 792 & $10.1-25.93$ & $106-223$ & $1.18-6.08$ & \\
\hline & $\begin{array}{l}\text { Atlas blidéen } \\
\text { Natif plantation }\end{array}$ & Humid & $1000-1200$ & $14-28$ & $95-128$ & $3.38-8.29$ & $0.4-3.68$ \\
\hline \multirow{6}{*}{ Algeria } & $\begin{array}{l}\text { Atlas Blidéen artificial } \\
\text { planting of } 1970\end{array}$ & Humid & 1200 & $12.28-16.65$ & $43-61$ & $5.27-11.42$ & $1.30-4.44$ \\
\hline & $\begin{array}{l}\text { Atlas blidéen artificial } \\
\text { planting of } 1930\end{array}$ & Humid & 1200 & $19.05-20.98$ & $51-102$ & $4.89-6.32$ & $2-4.04$ \\
\hline & $\begin{array}{l}\text { Atlas blidéen artificial } \\
\text { planting of } 1970\end{array}$ & Subhumid & 950 & $10.2-16.46$ & $77-94$ & $1.78-4.53$ & $5.78 \pm 1.59$ \\
\hline & $\begin{array}{l}\text { Atlas blideen artificial } \\
\text { planting of } 1970\end{array}$ & $\begin{array}{l}\text { Semi-arid } \\
\text { Subhumid }\end{array}$ & 680 & $10.55-12.32$ & $59-72$ & $1.03-1.98$ & $2.68 \pm 0.75$ \\
\hline & $\begin{array}{c}\text { Médea artificial } \\
\text { planting of } 1970\end{array}$ & Semi-arid & 523 & $4.93-12.87$ & $37-72$ & $0.35-2.42$ & $3.33 \pm 0.74$ \\
\hline & $\begin{array}{l}\text { Souk Ahras (El M'sid) } \\
\text { artificial planting of } 1970\end{array}$ & Humid & 900 & $6.5-20^{\star}$ & $95.6-146.6^{*}$ & $3.19-8.17^{*}$ & $\begin{array}{c}4.72 \pm 1.30^{\star} \\
2.64 \pm 0.97^{\star \star} \\
3.20 \pm 2.68^{\star \star \star}\end{array}$ \\
\hline
\end{tabular}

promote water infiltration (Widmann 1952, Monjauze 1960, Seigue 1985). These results correlate the one obtained by other authors reflecting the importance of deep soil anchorage for the cedar success in reforestation actions. Khorchi (2008) and Larbi-Rezig (2011) indicate that young cedars on deeply tilled soil grow from 3 to 7 times faster and are much less sensitive to precipitation declines compared to those on thin soil. For the cedar forest persistence over the quaternary period, Lecompte and Lepoutre (1975) explain it by the location of the forest on deep soil which limit the drought effect. They specify that only trees growing on substrates composed by volcanic ash, were able to overcome this difficult period, because the ashes soil is able to stores deeply significant water volumes. In the same context Savill and Wilson (2015) supposes that the resistance of cedar to eventually droughts related to the recent climate warming, will depend on the presence of depth soil.

Thus this work brings useful information for forests management in general and for cedar reforestation actions. Since the beginning of cedar trees decline since the 80s, due to the climate warming (Bentouati \& Bariteau 2006; Bentouati 2008; Linares et al. 2011), its use for reforestation in the South Mediterranean 
becomes less obvious. And Demarteau et al. (2007), estimate if the climate warming keep one and aridity period increase the 160,000 ha of cedar forest in North African will be strongly affected. Beloula (2010) reported already the dieback of 13,000 ha of cedar forest during the period 1955-2006. This works shows that the use of new plating technics came compensate in part or delay the ongoing rainfall decline and rainfall enhance annual variability.

\section{Conclusion}

The results of this study show the advantage of new planting methods to improve the resistance of cedar reforestation to climatic hindrance. In mountains area, the uses of hillside ditches strengthen the roots anchoring and the collection of soil moisture. On the North slope, such as the Souk Ahras Mountains which receive between 700 and $800 \mathrm{~mm}$ at an altitude of $1200 \mathrm{~m}$, the cedar reforestation records it higher productivity. The usefulness of this cedar reforestation in Algeria is well established, because of the presence of numerous mountains range with optimum altitudinal conditions. For instance, in the North part of Tellian Atlas mountains in the Blida region, the area above $1000 \mathrm{~m}$ of altitude can be used for cedar reforestation, exceeds 7000 ha (Dehilis \& Bouakline 2013). Usually, these areas receive $700 \mathrm{~mm}$ of rainfall, which is the minimum for the best growth of cedar. However, improvements of soil depth will limit the climatic hazard over the youngest plantations. The plantation on hillside ditches or on terraces is one of the methods to improve deep root soil anchorage, but this technique remains more expense, which is the only restriction for its wide scale use.

\section{Acknowledgements}

$\mathrm{S} M$ which conceived the study directed the work on the field and performed the statistical analysis, K A realised the measurements, the bibliographical research and commented the results, L L corrected and improved the manuscript. The authors would like to thank the foresters of S. Ahras department for their field assistance.

\section{References}

Beloula, S. (2010). Etude sur le dépérissement du Cèdre de l'Atlas dans le Parc National de Belezma (Wilaya de BATNA). Apport de la télédétection et SIG (60 p). Batna, Annexes: Mem. Mag. Sci. agr. univer.

Bentouati A., \& Oudjehih, B. (1999). Première étude de la croissance et de la productivité du Cèdre de l'Atlas (Cedrus atlantica Manetti) dans le massif de Bélezma (Aurés Algérie). Forêt Méditerranéenne, 20, 115-119.

Bentouati, A., \& Bariteau, M. (2006). Réflexions sur le dépérissement du Cèdre de l'Atlas des Aurès (Algérie). Forêt Méditerranéenne, 27, 317-322

Bentouati, A. (2008). La situation du cèdre de l'Atlas dans les Aurès (Algérie). Foret Méditerranéenne, 29, 203-208.

Chellabi, H. (1992). Contribution à l'étude de la productivité de Cedrus atlantica Manetti 
en fonction des facteurs stationnels et l'établissement d'un tarif de cubage. Cas du parc national de Chréa (54 p). Thèse d'ingénieur agronome, El Harrach (Alger): INA.

Cointat, M. (1996). Le roman du cèdre. Revue Forestière Francaise, 48, 503-526. https://doi.org/10.4267/2042/26773

Courbet, F., \& Alboudy, A. (1993). Modélisation dendrométrique de l'architecture du cèdre de l'atlas en peuplement, 191-207 in architecture des arbres fruitiers et forestiers I.N.R.A Montpellier France.

Courbet, F., Lagacherie, M., Marty, P., Ladier, J., Ripert, C., Riou-Nivert, P., Huard, F., Amandier, L., \& Paillassa, É. (2012). Atlas Cedar and Climate Change in France: Assessment and Recommendations (29 p). France: INRA.

Dehilis, A., \& Bouakline, D. (2013). Etude des possibilités d'extension des peuplements du Cèdre de l'Atlas (Cedrus atlantica Manetti) au niveau de l'Atlas blidéen (62 p). Thèse de Master, El Harrach: ENSA.

Demarteau, M., Francois, L., Cheddadi, R., \& Roche, E. (2007). Réponses de Cedrus atlantica aux changements climatiques passés et futurs; Responses of Cedrus atlantica when faced with past and future climatic changes. Tome, 1-2, 105-146.

Duplat, P., \& Perrotte, G. (1981). Inventaire et estimation de l'accroissement des peuplements forestiers (432 p). Paris: ONF (section technique).

El Azzouzi, K., \& Keller, R. (1998). Propriétés technologiques du bois de cèdre de I’Atlas (Cedrus atlantica Manetti). forêt métlitermnéenne $t$., $x / x, 11-33$.

Haddad, A. (1998). Contribution à l'étude de la productivité du cèdre de l'Atlas (Cedrus atlantica Manetti) en fonction des facteurs stationnels dans le parc national de Chréa (167 p). Thèse de magister, El-Harrach, Alger: I.N.A.

Harfouche, A., \& Nedjahi, A. (2003). Prospections écologiques et sylvicoles dans les cédraies du Bélézma et de l'Aurès à la recherche de peuplements semenciers et d'arbres plus. Rev. For. Fr. (biologie et écologie). 113-122.

Khorchi, A. (2008). Contribution à l'étude de l'extension du cèdre de l'Atlas "Cedrus atlantica Manetti" (cas du parc national de Chréa) (66 p.). Thèse Ing. Agro. INA, El-Harrach.

Laaribya, S., \& Belghazi, B. (2016). Dynamique et accroissement radial du Cèdre de de l'Atlas (Cedrus atlantica)—Cas de la forêt d'Azrou (Maroc). Nature \& Technologie, 14, 19-32.

Larbi Rezig, H. (2011). Cartographie et bilan des reboisements de Cèdre (Cedrus atlantica Manetti) au Parc National de Chréa (64 p.). Mem. Ing. Sci. Agr. ENSA, El Harrach, Alger.

Lecompte, M., \& Lepoutre, B. (1975). Bilan de l'eau et conditions d'existence de la cédraie dans le moyen Atlas basaltique (Maroc) (269 p.). Utilisation d'une analyse d'information mutuelle entre les espèces et les variables du milieu. Extrait des Annales de la Recherche forestière au Maroc Tome 15.

Lefievre, J., Carmeille, J., \& Mirlyaz, W. (2010). Etude sur le potentiel du Cèdre de l'Atlas dans le massif Dordogne/Garonne (16 p.). Journée Cèdre organisée par le CRPF Languedoc-Roussillon, l'Association Forestière de l'Aude.

Linares, J. C., Taïqui, L., \& Camarero, J. J. (2011). Increasing Drought Sensitivity and Decline of Atlas Cedar (Cedrus atlantica) in the Moroccan Middle Atlas Forests. Forests, 2011, 777-796. https://doi.org/10.3390/f2030777

Linares, J. C., Taïqui, L., Sangüesa-Barreda, G., \& Seco, J. I. (2013). Age-Related Drought Sensitivity of Atlas cedar (Cedrus atlantica) in the Moroccan Middle Atlas Forests. Dendrochronologia, 31, 88-96. https://doi.org/10.1016/j.dendro.2012.08.003

Meddour, R. (2002). Bioclimats, étages et séries de végétation de l'Atlas Blidéen (Algérie). 
Phytocoenologia, 32, 101-128. https://doi.org/10.1127/0340-269X/2002/0032-0101

Messaoudène, M., Loukkas, A., Janin, G., Tafer, M., Dilem, A., \& Joaquim, G. (2004). Propriétés physiques du bois d'éclaircie des cèdres (Cedrus atlantica), contenant du bois de compression, provenant de l'Atlas du Djurdjura (Algérie). Annals of Forest Sciences, 61, 1-7. https://doi.org/10.1051/forest:2004054

M’hirit, O., \& Benzyane, M. (2006). Le Cèdre de l'Atlas: Mémoire du temps (288 p). Ed. Mardaga.

M'hirit, O. (1994). Le cèdre de l'Atlas (Cedrus atlantica Manetti), présentation generale et etat des connaissances à travers le reseau Silve mediterranea Le cèdre. Ann. Rech. For. Maroc, 27, 3-22.

M'hirit, O. (1999). Le Cèdre de l'Atlas à travers le réseau silva mediterranea Cèdre. Bilan et perspectives. Foret Méditerranéenne, 20, 91-99.

Monjauze, A. (1960). Le reboisement sur rootage en plein et sur bourrelets. Revue Forestière Française, 1, 2-25. https://doi.org/10.4267/2042/24209

Nedjahi, A. (1987). La cédraie de Chréa (Atlas Blidéen). Phénologie productivité régénération (77 p.). Thes. Doct., université de Nancy.

Parde, J., \& Bouchon, J. (1988). Dendrométrie (2e édition, 328 p.). Ecole Nationale du Génie Rural, des Eaux et des forêts.

Rondeux, J. (1999). La mesure des arbres et des peuplements forestiers (521 p.). Gembloux: Les Presses Agronomiques de Gembloux.

Rondeux, J. (1993). La mesure des arbres et des peuplements forestiers (521 p.). Gembloux: Presses Agronomiques de Gembloux.

Sbabdji, M. (2012). Etude des infestations de la cédraie de Chréa par la processionnaire du pin, Thaumetopoea pityocampa Schiff: Description spatiotemporelle et interaction arbre-defoliateur (115 p.). Thèse de doctorat, Alger: ENSA, El Harrach.

Sbabdji, M., Lambs, L., Haddad, A., \& Kadik, B. (2015). Effect of Periodic Defoliations by Thaumetopoea pityocampa Schiff. on Radial Growth in Cedar Woodland in Chréa, Algeria. Revue d'Écologie, 70, 371-386.

Savill, P., \& Wilson, S. M. (2015). Species Profile Cedrus, True Cedars Silviculture and Properties. Quarterly Journal of Forestry, 109, 6 p.

Seigue, A. (1985). La forêt circumméditerranéen et ses problèmes (463 p.). Paris: Maisonneuve. Larose.

Toth, J. (1970). Plus que centenaire et plein d'avenir Le cedre en France. R.F.F., 22, 355-364. https://doi.org/10.4267/2042/20364

Toth, J. (1973). Première approche de la production potentielle du cèdre de l'Atlas dans le sud de la France. R.F.F., 25, 381-388. https://doi.org/10.4267/2042/20758

Toth, J. (1980). Le cèdre dans quelques pays du pourtour Méditerranéen et dans deux autres pays a grande. Forêt Méditerranéenne, 2, 23-30.

Toth, J. (1990). Croissance, sylviculture et production du cèdre de l'Atlas (Cedrus atlantica Manetti) implanté dans une zone naturelle de chêne vert (Quercus ilex L.) en région méditerranéenne française. In Actes du symposium international du cèdre, Antalya (Turquie) (pp. 963-973)..

Widmann, M. (1952). Banquettes et plants PUTOD. Revue Forestière Française, 9, 571-585. https://doi.org/10.4267/2042/27897

Zemirli, M. (2006). Contribution à l'étude écodendrométrique du Cedrus atlantica Manetti (cèdre de l'Atlas) dépéris dans le parc national de Theniet el Had (w. Tissemsilt) Algérie (82 p.). Thèse d'Ingénieur d'Etat, Ecologie et environnement, Université de Taret. 